\title{
Percepções do fenômeno urbano no século XIX sob a ótica literária de Victor Hugo em "Os Miseráveis"
}

\section{Amanda Carvalho Maia}

Arquiteta, mestranda no Programa de Pós-Graduação em Arquitetura, Tecnologia e Cidade da Faculdade de Engenharia Civil, Arquitetura e Urbanismo, Universidade Estadual de Campinas, R. Saturnino de Brito 224, Cidade Universitária, Campinas, SP, CEP 13083-889, (19) 3521-2417, amandacmaia1@gmail.com

\begin{abstract}
Resumo
Este trabalho apresenta reflexões sobre a contribuição da literatura na representação da cidade moderna e na construção do imaginário urbano através da interpretação da cidade de Paris sob o olhar de Victor Hugo na obra "Os Miseráveis". Paris torna-se modelo da metrópole e a capital do século XIX, representa o progresso do avanço científico e tecnológico e lócus da vida moderna. Através de uma perspectiva imaginária e simbólica, Hugo contempla a cidade como palco e personagem e descreve as contradições das relações e conflitos por meio da representação das mazelas sociais e das novas condições da vida urbana parisiense.
\end{abstract}

Palavras-chave: cidade moderna, Paris século XIX, Os Miseráveis.

século XIX foi marcado por transformações políticas e econômicas advindas das Revoluções Industrial e Francesa que impulsionaram o desenvolvimento tecnológico e conduziram a explosão demográfica que alterou as relações do homem com o espaço construído e com a natureza, além de acirrar os conflitos sociais. O desenvolvimento dessa nova cidade urbano-industrial remodelou as características organizacionais do espaço urbano, do trabalho e da sociabilidade adjuntos do sistema capitalista e culminou na construção de uma cultura e sensibilidade urbana moderna. Londres e Paris tornam-se paradigmas da sociedade moderna e símbolo do progresso.

A ideia de modernidade no século XIX emerge das novas experiências, sensibilidades, sentidos, ambiguidades, paradoxos e contradições que permeiam o imaginário coletivo em um ambiente de transformação do mundo físico e das relações sociais. Torna-se nítida a nova paisagem - palco da experiência moderna - formada por engenhos, máquinas, automação, ferrovias, fábricas e in- dústrias redundante do acirramento do Estado intervencionista, dos sistemas multinacionais de capital e do desenvolvimento dos sistemas de comunicação - jornais, telégrafos, telefones além da formação e expansão dos movimentos sociais de massa contrários a essa ambiguidade e incertezas adjuntas da modernização. Tal ambiente era atacado ou explorado pelos modernistas do século XIX sensíveis as novas possibilidades e movidos pelo desejo de mudança de autotransformação e transformação (BERMAN, 1986).

A novidade do fenômeno urbano serviu como palco para o discurso literário. Autores, cronistas e poetas participaram na construção do imaginário urbano, da identidade e de ideários sociais de modo a eternizar a memória através da sensibilidade coletiva. Segundo PECHMAN (199-):

"Nesse processo, pela primeira vez a cidade se torna foco de observação, análise e discurso. Basicamente, porque a cidade passa a representar a própria civilização na medida em que a vida urbana é 
vista como destino inexorável. Dito de outra maneira, a cidade é o laboratório onde a civilização moderna está sendo gestada" PECHMAN (199-).

Para PECHMAN (199-), a novidade urbana ancora-se na cidade povoada por uma multidão cuja qualidade básica é o individualismo, a destruição dos laços comunitários e das referências socioculturais que orientavam os habitantes. Para o autor, a multidão e o tempo abstrato apropriado pelo patrão (detentores dos meios privados de produção) fulgura a disciplina e o ritmo da população e define novas formas de dominação e sociabilidade baseadas na diferenciação social e feitichização da mercadoria que se tornam marca do novo fenômeno urbano.

Em outro texto, PECHMAN e PADILHA (1993) citam Carl Schorske e suas assimilações da cidade na qual, a partir do século XVIII, em sua filosofia iluminista, a cidade é caracterizada como virtude - sendo centro da política, do pensamento e da cultura através do "respeito da cidade pelo talento" segundo a Londres de Voltaire -, em contrapartida, a cidade do século XIX, procedente da industrialização, é caracterizada como vício, ou seja, "uma espécie de monstro com uma cabeça desmesuradamente grande, desproporcional ao corpo" e, em outra vertente, "a cidade além do bem e do mal", na qual o espaço urbano - palco da vida moderna - não pode ser ignorado sendo objeto de estudo

1 POE, E. A. Um homem na multidão. In: Os melhores contos de Edgar Allan Poe. Tradução por Oscar Mendes e Milton Amado. 3.ed. São Paulo: Globo, 1999. e pesquisa de literatos, arquitetos, engenheiros, médicos, sanitaristas, etc..

A representação da cidade "além do bem e do mal" de Carl Shorske é deveras encenada por Charles Baudelaire em sua interpretação das contradições da vida moderna retratadas pelos extremos dos vícios e virtudes, do luxo e da pobreza, do belo e do feio. Baudelaire manifesta a presença das multidões neste novo cenário urbano e introduz um herói moderno, o Flâneur, na figura de um transeunte invisível, camuflado e englobado na massa parisiense que caminha, vaga, perambula, apreende e observa a vida urbana no contexto de transformações da cidade do século XIX (SENRA, 2011). O Flâneur é, portanto, um leitor da cidade, um perfeito divagador que "[...] vê o mundo de uma maneira particular, sem a pretensão de explicar, mas com a intenção de mostrar, levando a vida para cada lugar que vê" (MASSAGLI, 2008).
O conto "Um homem na multidão", de Edgar Poe (1999) expressa a personificação do Flânuer urbano. Aqui, a personagem aparece na figura de um burguês que dispõe do seu tempo a contemplar e decifrar os sentidos da vida urbana. O conto se inicia com um homem, dentro de um café de Londres, observando ora o jornal, as personagens internas do café, ora os transeuntes externos. O observador se coloca, em primeiro momento, o desafio de decifrar e caracterizar tais figuras e, posteriormente, se infiltra na multidão a fim de investigar um personagem específico que aguçou sua curiosidade. Ambos os personagens, observador e observado passam mais de um dia em andanças nos labirintos das ruas de Londres absortos na multidão, este aparentemente sem propósito algum, àquele com o objetivo de decifrar os propósitos do primeiro. O olhar do personagem é fragmentado em consequência da apreciação de apenas alguns fragmentos da realidade vivenciada por ele, seus observadores e suas respectivas diferenciações sociais e espaciais demonstrando, desse modo, apenas partes das facetas do ambiente urbano e tecendo, portanto, a instigação da cidade como um mistério a ser desvendado.

Destarte, o Flânuer testemunha a anulação da personagem do homem moderno pela multidão, pela indiferença meio às inquietudes, pelo medo e tensões, estando o homem moderno condenado a perambular e a vaguear sozinho em meio a uma maré de gente 1 .

As Experimentações do mundo moderno no século XIX alteraram as relações do trabalho, do tempo, da rotina, da paisagem, do habitat e acarretaram percepções contraditórias da cidade. Máquinas, multidões e cidade tornam-se símbolos percussores do progresso e, ao mesmo tempo, representam a artificialidade (mecanização), inautenticidade (automatização dispensa a criatividade e o controle de todo o processo produtivo), impessoalidade, anonimato, desenraizamento (perda de identidade social) e destruição das referências físicas (o tempo passa a ser relacionado com as tarefas cíclicas e rotineiras do trabalho, não mais acompanha o ritmo da natureza). BRESCIANI (1985) utiliza como metáfora o termo de "monstros mecânicos" para representar a cidade moderna industrial do século XIX na qual faz alusão aos temores e medos do desconhecido, da população, da máquina, 
da ordem social - que traz a tona à ideia de um lugar perigoso, repulsivo ao mesmo tempo em que desperta admiração, fascínio e atração através da comoção do sublime.

Desta forma, a literatura possibilita eternizar a caracterização do espaço físico, das relações sociais, dos hábitos, da linguagem e do modo de pensar da época. O autor, como expectador privilegiado, realiza uma leitura do urbano, do cenário, das ruas e dos personagens que singularizam a cidade.

"Sobre tal cidade, ou em tal cidade, se exercita o olhar literário, que sonha e reconstrói a materialidade da pedra sob a forma de um texto. O escritor, como espectador privilegiado do social, exerce a sua sensibilidade para criar uma cidade do pensamento, traduzida em palavras e figurações mentais imagéticas do espaço urbano e de seus atores" (PESAVENTO, 1999, p. 09).

Destarte, Victor Hugo, Zola, Baudelaire, Eugène Sue, Edgar Allan Poe entre outros se colocaram o desafio de desvendar o enigma da cidade.

Portanto, apontamos a necessidade de um olhar interdisciplinar para o espaço considerando a possibilidade da abertura de uma esfera de oportunidades primordiais contidas nos escritos dos observadores, moradores e desfrutadores da época no intuito de ressuscitar reflexões e significados complexos sobre asserções emergentes em momentos específicos na sociedade. Destarte, tais leituras, interpretações e descrições estão abastadas de elementos conscientes e inconscientes, fruto das vivências coletivas - construção social da época - e privadas - do autor, em específico - capazes de fornecer informações além da exposição direta, mas que refletem o modo de ser e de pensar, não só do autor, mas de toda coletividade. Para tanto, procuramos colocar a relevância da utilização do romance e da poesia como recurso e fonte na obtenção de informações, referências, noções, elementos e aspectos que amparam estudos técnicos e empíricos na análise dos fatos de outrora na tentativa de sublevar outros olhares em contestação à simplicidade da tecnocracia e disciplinaridade.

Neste contexto, nos instigamos o desafio de apreciar a obra de Victor Hugo através de suas interpretações sobre a cidade de Paris sob o aspecto das novas condições da vida urbana num recorte do próprio autor que compreende o período de 1815 - batalha de Waterloo - a 1832 - motins de Junho - tomando como recorte no nosso objeto de estudo os cenários que tem como personagem principal a multidão, a representação da cidade através das metáforas, a nostalgia dos cenários campestres, a questão sanitária e, por último, as peculiaridades do habitat dos sujeitos pobre e rico.

Para o estudo, utilizamos uma edição de "Os Miseráveis" (Martin Claret, 2014) como instrumento para a leitura e investigação da cidade moderna, além da contribuição de obras de outros poetas juntamente com o aporte teórico de estudiosos concernentes às investigações e problematizações acerca das intervenções na cidade europeia e nas novas condições de habitabilidade do século XIX.

\section{L'homme du siècle}

Romancista, poeta, dramaturgo, pintor e político conhecido como "L'homme du siècle", Victor Hugo (1802-1885) perpassa todo o século XIX e se envolve com os conflitos de sua época. Experimentou os impactos pós-revolução francesa, guerras napoleônicas, motins de 1830, motins de 1848 e, posteriormente, a revolução de 1870 . Hugo vivenciou a consolidação do romantismo literato emergido pós-revolução francesa, onde o respectivo estilo se liberta do puro racionalismo classicista e passa a criticar os aspectos econômicos, políticos e sociais em voga, concedendo ao autor maior liberdade e autonomia para se aproximar da realidade.

Em meados do século XIX o hábito de leitura passa a envolver todas as classes sociais que buscam nas obras românticas de Hugo, Zola, Baudelaire, entre outros, sua representação (MENDES, 2014). O autor, atento às mudanças da apreensão do espaço urbano e das novas regras de convivência, transcorre para suas obras essa sensibilidade urbana, na qual constrói o ideário de Paris em "Os Miseráveis" como representação do bem e do mal e suas respectivas contradições. Os Miseráveis (romance, drama social e histórico) retrata de forma crítica a miséria, a pobreza, o sofrimento e os antagonismos políticos do período, bem como narra episódios das revoluções civis e sua repercussão na sociedade ressaltando assim, ora o dado histórico, ora o ficcional. 


\section{Princípios de uma grande doença}

"Multidão sem nome! Caos! Vozes, olhos, passos.

Aqueles que jamais se viam, aqueles que não se conhecem.

Todos vivos! - cidades atordoantes para os ouvidos.

Muito mais do que um bosque da América ou uma colméia de Abelhas"

La pente de la reverie - Feuilles d'Automne.

2 Hugo, V. Feuilles d' Automne. In: BRESCIANI, M. S $M$. Londres e Paris no século XIX: o espetáculo da pobreza. São Paulo: Brasileiense, 1998, pag. 7.

"Foule sans nom! chaos! des voix, des yeux, des pas.

Ceux qu'on n'a jamais vus, ceux qu'on ne connait pas.

Tous les vivants ! - cités bourdonnant aux oreilles.

Plus qu'un bois d'Amérique ou des ruches d'abeilles [...]"

Victor Hugo ${ }^{2}$

Os romancistas do século XIX manifestaram afinco Interesse pelo principal componente do novo cenário urbano: a multidão anônima - personagem de caráter heterogêneo e constituída por distintas classes sociais. Trata-se da multidão de operários que se acotovela em tempos fabris na ânsia de acompanhar e londrina e multidão insurreta que compõe a massa revolucionária. Multidão essa, paradoxal e o ritmo de produção, multidão suburbana parisiense conflituosa, símbolo da modernidade que representa as tensões do novo contexto urbano: anonimato, impessoalidade, perda de laços, individualidade, tédio, solidão e perdição meio a massa humana e na efervescência que é a cidade moderna. Em um instante, indiferente ao destino dos demais, no seguinte, demonstra solidariedade e união como forma de resistência meio a essa cidade hostil. São os grupos formados por pobres, estudantes, operários, homens e mulheres reivindicando suas necessidades, falando a linguagem política e dando corpo à revolução.

ENGELS (2010), em uma viagem a Londres no ano de 1840, analisa as condições de vida dos trabalhadores e descreve as mudanças advindas da revolução industrial demonstrando especial estranhamento na solidão e indiferença das multidões:

"[...] Esses milhares de indivíduos, de todos os lugares e de todas as classes, que se apressam e se empurram, não serão todos eles seres humanos com as mesmas qualidades e capacidades e com o mesmo desejo de serem felizes? E não deverão todos eles, enfim, procurar a felicidade pelos mesmos caminhos e com os mesmos meios? Entretanto, essas pessoas se cruzam como se nada tivessem em comum, como se nada tivessem a realizar uma com a outra e entre elas só existe o tácito acordo pelo qual cada uma só utiliza uma parte do passeio para que as duas correntes da multidão que caminham em direções opostas não impeçam seu movimento mútuo - e ninguém pensa em conceder ao outro sequer um olhar. Essa indiferença brutal, esse insensivel isolamento de cada um no terreno de seu interesse pessoal é tanto mais repugnante e chocante quanto maior é o número desses indivíduos confinados nesse espaço limitado; e mesmo que saibamos que esse isolamento do indivíduo, esse mesquinho egoísmo, constitui em toda a parte o princípio fundamental da nossa sociedade moderna, em lugar nenhum ele se manifesta de modo tão impudente e claro como na confusão da grande cidade [...]" (ENGELS, 2010, p.69).

A experiência de vivenciar a modernidade perpassa pela tentativa de encarar os impactos das aceleradas transformações do tempo e do espaço. Tais problemas e conflitos da vida moderna transcorrem na luta do indivíduo com a natureza pela sua existência física e na tentativa de autopreservação psíquica a fim de manter sua autonomia, liberdade e individualidade em meio às novas relações sociais regidas pelo modo de produção capitalista. SIMMEL (1977) expõe a recusa do cidadão metropolitano em reagir às bruscas transformações e aos estímulos configurados pelas novas situações e signos sendo levado a assumir uma atitude blasé perante as situações cotidianas.

\section{As efervescências de outrora, originalidade de Paris}

Os poetas romanescos representam as cidades do século XIX através de metáforas por meio da difícil tarefa de descrever os sentimentos de medo, estranhamento, fascínio, terror e espanto emanados da experiência modernista. Recorrem então a metáforas inspiradas em elementos da natureza, sentimentos e paixões humanas.

Retratam as ideias e discursos iluministas de progresso que exaltam o desenvolvimento industrial e cultural ao mesmo tempo em que colocam como paradoxo apontamentos e críticas aos efeitos destrutivos do acelerado avanço da tecnologia, e suas implicações nas novas formas de sociabilidade. Hugo retrata Paris como sujeito violento e cínico, produto e produtor das mazelas sociais - miséria, sujeira, multidão, desemprego, epidemias, vícios - como preço à miragem do progresso modernista. 
"Paris sempre mostra os dentes; quando não está ralhando, está rindo.

Assim é Paris. As fumaças de seus telhados são as ideias do universo. Amontoado de barro e de pedras, se assim quisemos, mas, acima de tudo, ente moral. É mais do que grande, é imensa. Por quê? Porque ousa.

Ousar; é o preço do progresso". (HUGO, 2014, p. 635)

O autor demonstra o fascínio perante a grande cidade industrial, abrigo das multidões e antro de todos os tipos de pessoas e sujeitos. Descreve as percepções contraditórias da cidade: palco da universalidade e cultura, aberta e acolhedora ao mesmo tempo em que destrói, esmaga e consome, onde tudo se acha e tudo se perde. É a cidade que representa o mundo: o mundo está em Paris. Cidade moderna e tradicional que suplanta o espírito revolucionário ao mesmo tempo em que deseja manter os hábitos e costumes tradicionais.

[...] Paris é um lugar onde tudo se perde, e tudo desaparece nesse umbigo do mundo como desapareceria no umbigo do mar. Nenhuma floresta esconde um homem como aquela multidão. Os fugitivos de todo tipo sabem disso. Vão a Paris como a um sorvedouro; há sorvedouros que salvam. A polícia também sabe disso, e é em Paris que ela procura o que perdeu em outro lugar [...]". (HUGO, 2014, p. $511-512$ )

"Paris é um total. É o teto do gênero humano. Toda essa cidade prodigiosa é um resumo dos costumes mortos e dos costumes vivos. Quem vê Paris acredita ver o avesso de toda a história, com céu e constelações nos intervalos". (HUGO, 2014, p.631)

"Paris, essa cidade modelo, padrão das capitais bem construídas, da qual cada povo procura ter uma cópia, essa metrópole do ideal, essa pátria augusta da iniciativa, do impulso e da tentativa, esse centro e lugar dos espíritos, essa cidadenação, colmeia do futuro, composto maravilhoso de Babilônia e Corinto, faria, do ponto de vista que acabamos de assinalar, encolher os ombros a um camponês do Fo-Kian.

Imitem Paris, e estarão arruinados". (HUGO, 2014, p. 1307)
A transformação do espaço urbano, causada pelas grandes reformas, foi fundamentada na vontade modernizante de suprir as novas necessidades dos citadinos burgueses e trabalhadores, adequandoos à nova realidade de consumo industrial além do propósito de erradicar com as mazelas sociais, físicas, morais e sanitárias dos pobres que atrapalhavam os ritmos e fluxos de produção.

Hugo descreve a mudança na estética arquitetônica e esclarece sua atribuição ao "poder" corretivo do progresso. Abaixo, no primeiro trecho retrata os arredores do bairro Corinto no início da década de 1830 e caracteriza as ruas e vielas como estreitas, irregulares e escuras tomadas por construções altas e de diferentes dimensões construídas por acaso e utilizadas por comércio e cortiços, expugnadas pela sujeira e imundície. No segundo trecho, descreve as transformações e substituições pela qual a cidade estava se transfigurando.

"Dizemos fendas estreitas, e não poderíamos dar uma ideia mais justa daquelas ruelas obscuras, apertadas, angulosas, ocupadas com casebres de oito andares. Esses casebres estavam tão decrépitos que, nas ruas de La Chanvrerie e de La Petite-Truanderie, as fachadas sustentavam-se em vigas que iam uma casa a outra. A rua era estreita e o canal largo; os passantes caminhavam sobre um calçamento sempre molhado, beirando lojas que pareciam porões, grandes marcos cercados de ferro, enormes montes de lixo, entradas de alamedas guarnecidas com enormes grades seculares. A Rua Rambuteau devastou tudo isso". (HUGO, 2014, p.1128)

"O ponto de Paris em que Jean Valjean se encontrava, situado entre o arrabalde de Santo António e a Rapée, é um dos que foram transformados completamente pelas recentes obras, tornando-se feio segundo uns, transfigurando-se segundo outros.

As hortas, os depósitos e as velhas construções desapareceram. Hoje, há grandes ruas novas, arenas, circos e hipódromos, a estação ferroviária, e uma prisão, Mazas; o progresso, como se vê, com o seu corretivo". (HUGO, 2014, p. 495)

O tempo e espaço, agora dominados pelos aparatos tecnológicos, foram reordenados para seguir o ritmo da produção industrial. As novas configurações de trabalho, tecnologias e produtos criaram novos 
hábitos, formas de viver e regras sociais. Dessa forma, o trabalho passou a ser visto como primordial tendo a sociedade o dever de eliminar os indivíduos que não ajustassem aos novos ritmos, recaindo sobre os menos abastados toda a culpa por sua situação de miséria.

Vitor Hugo alardeia sobre o interminável ciclo do trabalho e seus impactos - miséria, pobreza, exaustão e indiferença - na nova sociedade emergente: o operariado. O autor também expõe o desejo de mudança e revolta que assolava a população, agora com possibilidade de acesso à leitura e atenta aos ideários e acontecimentos da revolução Francesa, no contexto do absolutismo do rei Luiz Felipe I.

"Esse antigo subúrbio, populoso como um formigueiro, laborioso, corajoso e bravo como um enxame de abelhas, estremecia com a espera e o desejo de uma comoção. Tudo ali se agitava, sem que por isso o trabalho fosse interrompido. Nada poderia dar uma ideia dessa viva e sombria fisionomia. Nesse bairro, há misérias pungentes escondidas sob os tetos de mansardas; mas ali também há inteligências ardentes e raras. É especialmente em função da indigência e da inteligência que é perigoso quando dois extremos se toquem". (HUGO, 2014, p. 894)

\section{A relva esconde e a chuva apaga}

As transformações da cidade, dos ritmos e fluxos advindos da aceleração afetaram e impactaram as relações humanas e de interdependência do homem com a natureza. As novas experiências humanas foram obrigadas a abdicar sua subjetividade e identidade para aderir às novas relações objetivas. As atividades humanas não mais seguem os ritmos e ciclos naturais tornando o tempo linear e abstrato controlado pelas novas tecnologias (vela, iluminação a gás e energia elétrica). Desta forma, o homem se coloca como "vencedor da natureza", perdendo vínculos indenitários e de orientações conforme os ciclos naturais, estabelecendo assim, uma nova condição de vivência no mundo moderno.

Ademais, verifica-se uma mudança na percepção do tempo - tempo irregular da natureza e do calendário religioso para o tempo da máquina e do processo de produção fabril e de calendários comerciais. A industrialização substitui o ciclo natural dos dias e estações pelo relógio, símbolo de controle e regulador - da longa jornada de trabalho, do horário de saída e entrada dos operários -, da escola - papel disciplinador - e do trem - pontualidade. Também houve a imposição de uma nova forma de gestão do tempo atenta para a reestruturação do período do trabalho e período de repouso e lazer a fim de dinamizar as atividades produtivas e criar novos hábitos de consumo. No âmbito da vida privada os espaços residenciais passaram por uma reorganização funcional para diminuir o tempo das realizações domésticas e liberar mão de obra feminina para as fábricas (CORREIA, 1996).

No contexto dos problemas urbanos - pobreza, miséria, endemias, destruição moral e pressa ressurge a convicção do campo como local ideal. Para os pobres, a concepção de vilas operárias localizadas em núcleos fabris afastados da cidade seria o local de resgate dos preceitos morais, disciplina e higiene que aumentariam a capacidade de produção do trabalhador. Para a burguesia - através de indicação médica de temporadas junto à natureza e banhos de mar - local de repouso, lazer e descontaminação da poluição, dos ruídos e cheiro da cidade industrial.

Na ótica literária, a ambientação do cenário campestre no chamado romance regionalista assume o caráter nostálgico da vida rural como refúgio dos conflitos citadinos e local de regeneração física e moral. Jane Austen, Heny James, Lawrance, Powys, Constant Holme, entre outros descrevem a paisagem e a poesia da natureza. Os romancistas discorrem sobre a vida rural como cenário das paixões naturais e encaram os habitantes das cidades como grosseiros, sujos, e desrespeitosos das riquezas naturais. Portanto, a retratação do campo emergia de uma:

"[...] estrutura de sentimentos em que a terra e suas criaturas - animais e camponeses quase em pé de igualdade - consistiam uma afirmação da vitalidade e da possibilidade de repouso conscientemente contrastada com a ordem mecânica e as rotinas artificiais da cidade [...]". (WILLIAMS, 1989, p.339)

A obra de Vitor Hugo passa longe de se enquadrar no estilo regionalista, mas descreve a cidade como um ambiente hostil, hipócrita, tenebroso, angustiante e melancólico. A retratação do ambiente urbano é sempre negativa. Em contraponto, os únicos ambientes de compleição positiva são os de caráter campestre, tendo nos jardins urbanos espaços de 
refúgio - da agitação advinda da vida moderna -, lazer - local de descanso, calmo, sereno e repleto de vida e natureza - e regeneração - física e mental - sendo o único recinto admirado por todos os citadinos parisienses.

"Aquele dia foi, do começo ao fim, uma aurora. Toda a natureza parecia repousar e sorrir. Os canteiros de Saint-Cloud exalavam perfumes; a brisa do Sena agitava brandamente as folhas; os galhos gesticulavam ao vento; as abelhas saqueavam os jasmins; as borboletas pousavam aos bandos nas mil - folhas; trevos e aveias; no augusto parque do rei de França via-se um bando de vagabundos, os pássaros". (HUGO, 2014, p.168)

O autor demonstra profunda nostalgia aos tempos de outrora e descreve tanto as mudanças na estética urbana como as transformações do espaço rural que adquiriu a característica aceleração das cidades.

"Mal se imagina hoje o que, há quarenta e cinco anos, era um passeio de estudantes e costureiras no campo. Paris já não tem os mesmos arredores; Aquilo que se podia chamar de vida circumparisiense vem mudando completamente há meio século. Onde passava a carruagem, passa uma locomotiva; onde navegava a barca, navega o vapor; fala-se hoje em Fécamp como então se falava em Saint-Cloud. Paris de 1862 é uma cidade que tem a França como arrabalde". (HUGO, 2014, p. 164)

"Há vários anos que o autor deste livro, obrigado a contra-gosto a falar de si mesmo, vive fora de Paris. Depois que saiu de lá, Paris transformou-se; surgiu uma nova cidade, que de certo modo Ihe é desconhecida. Nem é preciso dizer que ama Paris; Paris é a cidade natal do seu espírito. Após demolições e reconstruções, a Paris da sua juventude, a Paris que religiosamente vem trazendo em sua memória, a esta altura é uma Paris de antigamente [...]". (HUGO, 2014, p. 489)

\section{A cloaca e suas surpresas}

Meio aos problemas urbanos da nova cidade emergente - doenças, endemias, sujeira, e "promiscuidade" -, a questão sanitária e as formas de habitabilidade do pobre tornaram-se epicentros de pesquisas da administração pública. Restritas a aptidões físicas e comportamentais técnicas - relacionadas ao sistema de esgoto, sistema de drenagem, limpeza urbana e coleta e abastecimento de água - tais pesquisas fundamentaram as intervenções urbanas sanitárias e arquitetônicas e disseminaram a ideia de reforma da cidade, da casa e da família, estabelecendo novas formas de morar - modos de funcionamento da casa - e novas regras comportamentais - família como núcleo de resguardo e proteção da imoralidade, e disseminação de novos hábitos de higiene com a casa e com o corpo - a essa parcela da população. O Estado, situado no controle sobre os mecanismos de salubridade e higiene, consegue conceber a domesticação dos pobres através do domínio de mecanismos que proporcionam a satisfação corporal que é capaz de exercer forte influência física e moral (BEGUIN, 1992).

A constatação dos médicos e engenheiros fundamentava que os ambientes insalubres deterioravam a saúde da população e denotava como um obstáculo ao desenvolvimento moral dos pobres acarretando em um fardo econômico (alta taxa de mortalidade, baixa expectativa de vida, ilegalidade e moralidade) que desestimulava o processo de produção. Hugo adere ao discurso sanitarista em voga e defende as novas concepções de salubridade relacionadas à circulação do ar e da luz, melhoria da limpeza pública, abastecimento e, principalmente, o sistema de drenagem e evacuação. O autor demonstra admiração às cloacas parisienses, construídas já no século XIII, e dedica todo um capítulo à história e à importância dos esgotos para a cidade das luzes. Critica, também, a exposição dos dejetos urbanos diretamente no Sena e argumenta a diminuição dos problemas urbanos através de uma nova economia de controle social juntamente com a drenagem e evacuação adequada.

"Paris segue esse exemplo com toda a estupidez própria das cidades inteligentes.

Para as necessidades da operação sobre a qual acabamos de nos explicar, Paris tem debaixo de si outra Paris; uma Paris de esgotos, que tem suas ruas, encruzilhadas, praças, largos, becos, artérias e circulação, que é lodo, mas subtraída da forma humana". (HUGO, 2014, p. 1308)

"[...] Quando a drenagem, com sua dupla função, restituindo o que toma, tiver substituído o esgoto, simples lavagem empobrecedora, então, combinando 
isso com os dados de uma nova economia social, o produto da terra será decuplicado, e o problema da miséria será singularmente atenuado. Acrescentem a isso a supressão dos parasitismos e estará resolvido" (HUGO, 2014, p. 1307).

Ademais, Hugo narra, através do discurso do padre Myriel, que as condições de precariedade de construção das residências do operariado em relação às aberturas que poderiam condicionar melhor iluminação, ventilação e consecutivamente refletir na saúde da população é fomentada pelo próprio Estado que colocava como requisito de cobrança de impostos a quantidade de portas e janelas das moradias.

"Caríssimos irmãos, meus bons amigos: na França, há um milhão, trezentas e vinte mil casas de camponeses que só têm três aberturas; um milhão, oitocentas e dezessete mil que têm duas aberturas, uma porta e uma janela; e, finalmente, trezentas e quarenta e seis mil cabanas, cuja única abertura é a porta. E isto por causa do denominado imposto de portas e janelas! Coloquem pobres familias, velhas senhoras e criancinhas dentro dessas habitações e, verão as febres e as doenças! Oh! Deus dá o ar aos homens e a lei os vende! [...] . (HUGO, 2014, p. 52)

\section{Tal dono, tal casa}

Junto às críticas referentes aos problemas urbanos (casas, pessoas, organização da cidade e do trabalho), o ambiente passa a ser visto como mediador e influenciador da moral e dos costumes do pobre. Surgem, portanto, propostas de reforma do meio na qual tem a residência privada como "fundamento material da família e pilar da ordem social". Assumindo caráter moral e político, a reforma da casa assume novas referências de economia doméstica que pressupõe vida equilibrada e autônoma baseada no núcleo familiar e sustentada nas novas questões de habitabilidade e sentidos simbólicos que pressupõe higiene (ar puro, salubridade, calor e limpeza), proteção (intempéries) - e contraposição (oposição indústria/lar) (PERROT, 2009).

Hugo descreve os espaços internos de moradia como influído pelo caráter dos moradores e vice-versa. O autor caracteriza o interior do edifício Gorbeau como ambiente desintegrador, melancólico, sombrio, desagradável e sujo. Aqui, a organização espacial do prédio tem como eixo principal um corredor escuro na qual se abrem celas com características e tamanhos variados. Cada cela era ocupada por toda uma família e servia como local para a realização de diversas funções, considerando todas as atividades cotidianas familiares, desde o descanso e lazer até o cozimento e o trabalho.

"A escada conduzia a um edifício muito vasto, que se assemelhava a um galpão transformado em casa. Esse edifício tinha como tubo intestinal um longo corredor para o qual se abriam, à direita è̀ esquerda, espécies de compartimentos com dimensões variadas, a rigor habitáveis, e mais parecidos com tendas do que com celas. Esses quartos recebiam claridade dos terrenos vagos em volta. Tudo isso era obscuro, desagradável, descorado, melancólico, sepulcral, atravessado, segundo as fendas no telhado ou na porta, por raios frios ou rajadas geladas. Uma particularidade interessante e pitoresca desse tipo de habitação é o tamanho das aranhas". (HUGO, 2014, p. 475)

Adentrando o recinto chegaremos aos microespaços das celas, os quais Hugo pormenoriza suas características equiparando-os a seus ocupantes. Aqui, novamente, há a comparação entre os espaços citadinos e os naturais e instiga a preferência do mundo selvagem ao caráter do homem.

"As cidades, assim como as florestas, têm seus antros nos quais se esconde tudo o que elas encerram de mais tenebroso e perverso. Com a diferença de que, nas cidades, o que assim se esconde é feroz, imundo e pequeno, isto é, feio; nas florestas, o que se esconde é feroz, selvagem e grande, quer dizer, belo. Covil por covil, o dos animais é preferível ao dos homens. As cavernas são melhores do que as espeluncas". (HUGO, 2014, p. 786)

O autor continua sua comparação relacionando a cela da personagem Mário e a dos falsos Jondrettes (Thenardier) através do olhar do primeiro que espia por uma fenda e caracteriza o quarto ao lado ocupado pela família Thenardier.

"O que Márius via era uma espelunca.

Mário era pobre, e o seu quarto era indigente; mas do mesmo modo que sua pobreza era nobre, seu 
quarto era limpo. O chiqueiro em que seu olhar mergulhava naquele momento [espelunca Jondrette] era abjeto, sujo, fétido, infecto, tenebroso, sórdido. Os únicos móveis eram uma cadeira de palha, uma mesa manca, alguns cacos velhos e, em dois cantos, duas miseráveis camas indescritiveis; a única claridade vinha de uma janela de quatro vidros coberta de teias de aranha. Por este postigo entrava somente a luz necessária para que o rosto de um homem parecesse o rosto de um fantasma. As paredes tinham um aspecto leproso, estavam cobertas de remendos e cicatrizes, como um rosto desfigurado por alguma horrivel doença. Uma umidade viscosa brotava delas. Divisavam-se ali desenhos obscenos feitos, grosseiramente, com carvão.

O aposento que Mário ocupava era pavimentado com tijolos deteriorados; este, nem era ladrilhado nem assoalhado; pisava-se nu em cima do antigo reboque que se tornara encardido com o tempo. Nesse piso desigual, em que o pó estava como que incrustado, e que só tinha uma virgindade, a da vassoura, agrupavam-se caprichosas constelações te tamancos, chinelos velhos, e trapos medonhos; de resto, no quarto havia uma lareira, que também era alugada por quarenta francos anuais. Tinha de tudo naquela lareira: um fogareiro, um caldeirão, umas tábuas quebradas, uns farrapos pendurados em pregos, uma gaiola, cinzas e até mesmo um pouco de fogo. Dois tições ali fumegavam tristemente.

Tinha uma coisa que acrescentava ainda mais horror a esse chiqueiro [Jondrette], era o fato de ser grande. Tinha saliências, ângulos, buracos escuros, desvãos, vãos e promontórios. E aí, medonhos cantos insondáveis onde deveriam esconder-se aranhas grandes como um punho, lacraias grandes como um pé, e talvez até mesmo não se sabe que seres humanos monstruosos". (HUGO, 2014, p. 786 - 787)

O autor exprime as características de Mário como pobre, mas digno e asseado e, da mesma forma, descreve o ambiente em que ocupava. Quanto à cela dos Jondrettes, foi descrita como obscura, fétida, tenebrosa e sórdida na mesma medida em que descreve o caráter dos seus habitantes. A família Thenardier, agora sob a fachada do sobrenome Jondrette, era inicialmente composta por sete membros na qual dois filhos foram "vendidos" e o outro foi relegado às ruas de Paris sobrando, portanto, como núcleo familiar ocupante daquele recinto, apenas os pais e as duas filhas. Hugo minudencia o cubículo dos Jondrettes, como possuidor de fendas e cantos obscuros, antro de seres monstruosos - remetido aos insetos e aos próprios moradores - com paredes de aspecto leproso cobertas de costuras e cicatrizes - relação à miséria e ao cinismo e falsidade dos ocupantes - na qual distinguiam desenhos obscenos feitos de carvão - referência à linguagem utilizada aos homens da caverna remetidos ao atraso, subdesenvolvimento e inconsistência dos próprios habitantes.

Em outro contexto, Hugo descreve as características físicas e espaciais de uma residência burguesa. Aqui, a personagem principal é o avô de Mario, Sr. Gillenormand, sujeito conhecedor das artes e modismos da época, frequentador dos grandes salões parisienses e que dispõe como fonte de sua riqueza a herança de uma tia-avó. A planta da residência era composta por diversos espaços determinados por sua função. Os ambientes internos eram repletos e enaltecidos por móveis grandes e pomposos com o intuito de valorizar o status do seu ocupante. Tais espaços eram forrados por tapeçarias, cortinas e espelhos justamente para se distinguir das paredes nuas dos cortiços, antro dos pobres. A casa possui, também, varandas e jardins como elementos de proteção e privacidade à vida exterior.

"Ocupava um antigo e amplo aposento no primeiro andar, entre a rua e os jardins, forrado até ao teto com grandes tapeçarias dos Gobelins e de Beauvais representando cenas pastoris; os temas que apareciam no teto e nos painéis repetiam-se em ponto pequeno no estofado das poltronas. Envolvia sua cama com um biombo de nove folhas em laca de Coromandel. Longas cortinas pendiam das janelas formando um magnífico pregueado. o jardim, situado logo abaixo de suas janelas, ligava-se a uma delas, de canto, por meio de uma escada de dez ou quinze degraus, pela qual o bom Gillenormand subia e descia com toda a alegria. Além de uma biblioteca contígua a seu quarto, tinha um toucador do qual gostava muito, local elegante, forrado por uma lindíssima tapeçaria de palha, com flores-de-lis e outras estampas, feitas nas galés da época de Luís XIV, por ordem do senhor Vivonne a seus forçados, para sua amante [...]". (HUGO, 2014, p. 641) 
Cabe ressaltar aqui, que a figuração de tais espaços está compreendida no período entre as três primeiras décadas do século XIX. Momento anterior à retratação e investigações a cerca dos problemas urbanos causados pelas endemias e mazelas que seria atribuída às questões sanitárias de higiene e que irá dar suporte às novas condições de habitabilidade e formas de economia doméstica, principalmente como meio de domesticação do pobre.

\section{Considerações finais}

Hugo emprega em suas obras a preleção moralista de sua época. Cabe ressaltar aqui, que o autor se dedicou, também, a vida política e religiosa e se enquadrava no perfil reformista. Em "Os Miseráveis", Hugo demonstra claramente sua visão política, princípios e ideais através da caracterização de seus protagonistas: Jean Valjean representa a potência do trabalho como condição para a ascensão social; Javaret figura o Estado alicerçado nas premissas morais da classe dominante; Fantine, a mulher abandonada pelo Estado, julgada e condenada pela sociedade que vê na prostituição sua única saída para a sobrevivência; Cosete, a exploração infantil; Mario, a juventude revolucionária apartidária da ordem; Gavroche o menino de rua, expugnado da infância, filho de Paris; e, finalmente, o comportamento dos Thenadier reflete a miséria, pobreza e injustiça que absorveram do meio em que vivem, são sobreviventes.

Em "Os Miseráveis" HUGO (2014) denuncia toda a pobreza, miséria e injustiça social do pretenso progresso urbano. Considerando que o romance passou a ser acessível para todos os públicos, Hugo usa a literatura como arma de denúncia, através da construção estética da cidade e seus conflitos, para sensibilizar as multidões indiferentes. Nas palavras do próprio autor: "enquanto houver lugares onde seja possível a asfixia social; em outras palavras, e de um ponto de vista mais amplo ainda, enquanto sobre a terra houver ignorância e miséria, livros como este não serão inúteis".

As transformações da cidade do século XIX, frente ao novo fenômeno urbano alteraram as condições de vida - ruptura com o passado e mudança dos hábitos e da cultura tradicional - e compôs um novo imaginário da cidade. As metrópoles, cenário da vida moderna, foram tratadas, pelos romancistas da época, como palco e personagem e figuraram o sentimento do sublime frente às transformações capitalista de autoconstrução destrutiva baseadas no discurso de progresso, incentivando o leitor a atentar-se à nova complexidade do fenômeno urbano.

Portanto, as contribuições literárias, bem como as representações artísticas de pinturas e gravuras, face a emergência do romantismo, foram bastante ricas para a representação do novo cenário urbano e apreensão das novas condições de vida urbana. Paris, capital do progresso, simboliza a identidade da vida moderna e a nova cultura urbana baseada na indiferença, artificialidade, inautenticidade, mecanicidade e velocidade sensivelmente captadas pelo olhar de Victor Hugo.

\section{Referencias bibliográficas}

BEGUIN, F. As maquinarias inglesas do conforto. Espaço e Debates, n 34, 1992

BERMAN, M. Tudo que é sólido desmancha no ar: a aventura da modernidade. Trad. Carlos Felipe Moisés; Ana Maria L. loratti. São Paulo: Companhia das Letras, 1986.

BRESCIANI, M. E.M. Metrópoles: As faces do monstro urbano: as cidades no século XIX. Revista Brasileira de História, São Paulo, ANPUH, Editora Marco Zero, v. 5, n. 8/ 9, 1985.

CORREIA, T. B. Espaço, tempo e cidade: as tecnologias da velocidade e o ambiente urbano. In: XX Encontro nacional da ANPOCS, 1996, Caxambú. ANPOCS.

ENGELS, F. A situação da classe trabalhadora na Inglaterra. Tradução por B. A. Schumann. São Paulo: Boitempo, [1860] 2010. Pag. 69.

HUGO, V. Feuilles d'Automne. In: BRESCIANI, M. S. M. Londres e Paris no século XIX: o espetáculo da pobreza. São Paulo: Brasileiense, 1998

HUGO, V. Os Miseráveis. Tradução por Renina Célia de Oliveira. São Paulo: Martin Claret, [1860] 2014.

MASSAGLI, S. R. Homem da multidão e o flâneur no conto 'O homem da multidão' de Edgar Allan Poe. Terra roxa e outras terras, v. 12, p. 55-65, jun. 2008. Disponível em: <www.uel.br/ pos/letras/ terraroxa/g_pdf/vol12/TRvol12f. pdf> Acesso em: 15 maio 2016 .

MENDES, M. L. D. Victor Hugo. UNIVESP TV.. Disponível em < https://www.youtube.com/ watch? $\mathrm{v}=\mathrm{mxVK}$ -6tniyE > visualizado em 22 jun. 2016.

PECHMAN, R. M. Pedra e Discurso: cidade, História e Literatura. Revista Semear, Rio de Janeiro, n. 3, [199-]. Disponível em: <htpp://www.letras.pucrio. br/catedra/revista/3Sem_06.html>. Acesso em: 12 maio. 2016. 
PECHMAN, R. M; PADILHA, N. O Urbano: invenção ou descoberta? Para pensar uma história urbana. In: II Seminário de História da Cidade e do Urbanismo, 1998, Salvador. Cidade e Urbanismo. História, Teorias e Praticas.

SALVADOR: ANPUR, 1993. p. 29-34. Disponível em < http://unuhospedagem. com.br/revista/rbeur / index.php/shcu/article/view/309/285 >. Acesso em 12 maio 2016.

PERROT, M. Maneiras de morar. In: Ariés, Philippe \& Duby, Georges (org.). História da vida privada: da Revolução Francesa à Primeira Guerra. Companhia das Letras: São Paulo, vol. 4, parte 3, pp. 284-302, [1987]2009.

PESAVENTO, S. J. O imaginário da cidade: visões literárias do urbano. Porto Alegre: Editora da Universidade / UFRGS, 1999, pag.09.
POE, E. A. Um homem na multidão In: Os melhores contos de Edgar Allan Poe. Trad. Oscar Mendes e Milton Amado. 3. ed. São Paulo: Globo, 1999.

SENRA, M. A cidade moderna: história, memória e literatura - Paris, Belo horizonte. Revista Univap, São José dos Campos, v. 17, n. 29, ag./2011. Disponível em < http://revista.univap. br/ index. php/revistaunivap/ article/ view/13/20> Acesso em 15 maio 2016.

SIMMEL, G. A metrópole e a vida Mental. Tradução de Sérgio Marques dos Reis. In: VELHO O. G. O Fenômeno Urbano: Organização e introdução. Rio de Janeiro: Zahar, 1977

WILLIAMS, R. O Campo e a Cidade na história e na literatura. Tradução por Paulo Henrique de Britto. São Paulo; Cia das Letras, 1989, pag. 339 